\title{
THE OPPORTUNITIES FOR USE THE PEER LAND EXCHANGE DURING LAND MANAGEMENT IN UKRAINE
}

\author{
Mykola MALASHEVSKYI ${ }^{1 \mathbb{D}}$, Alena PALAMAR ${ }^{2 * \mathbb{(}}$, Mariia MALANCHUK $^{3}$, \\ Olena BUGAIENKO ${ }^{(\mathbb{B}}$, Evgen TARNOPOLSKY ${ }^{(\mathbb{B}}$ \\ ${ }^{1}$ Department of Land Management and Cadastre, Sumy National Agrarian University, \\ 160, Gerasim Kondratiev Str., 40000, Sumy, Ukraine \\ ${ }^{2}$ Department of Geodesy, Kryvyi Rih National University, 11, Vitaly Matusevich Str., 50027, Kryvyi Rih, Ukraine \\ ${ }^{3}$ Department of Cadastre of Territory, Lviv Polytechnic National University, 12 Bandera Str., 79013, Lviv, Ukraine \\ ${ }^{4}$ Department of Land Management and Cadastre, Kyiv National University of Construction and \\ Architecture, 31, Povitroflotsky Ave., 03680, Kyiv, Ukraine \\ ${ }^{5}$ Communal enterprise Kiev Institute of Land Relations 32-a, \\ Khreshchatyk Str., 01001, Kyiv, Ukraine
}

Received 10 September 2018; accepted 15 November 2018

\begin{abstract}
The preconditions and general directions of inter economic land surveying in the modern conditions of Ukrainian in accordance to the perspectives of peer land exchange implementation have been analyzed. The measures, implementation of which is advisable based on peer land exchange as the key mechanism have been singled out and substantiated. According to the current legislation of Ukraine, the main types of documentation for land management, which may provide the peer land exchange are defined.

Land exchange is a common way of streamlining existing land ownership and land use in domestic and foreign practice. In particular, an equivalent exchange is often aimed at regrouping a significant amount of land use in order to optimize their structure. At the present time, the coordination of the interests of landowners in the process of optimizing the multitude of land uses of settlements is of particular relevance. For example, there is a need to locate facilities that have environmental and social significance, improvement and changing boundaries of land management objects at different levels. In the context of certain tasks, given the legally defined issue of exchange agreements concluding, the settlement of the land exchange process requires a technical justification.
\end{abstract}

Keywords: land exchange, land tenure reorganization, land surveying project, sustainable land use.

\section{Introduction}

The formation of a rational system of land tenure and land use depends on the variable social and economic conditions. Therefore, the emergence of the need for reorganization of the territory is natural. Today in Ukraine there are a number of unresolved issues on the verge of a collision of landowners interests, which indicates the lack of effective mechanisms for the land redistribution.

Therefore, it is urgent to find the common technical solutions for the land tenure and land use reorganization, both for resolving the urgent tasks of area spatial organization improvement and for future planning. The issue of spatial territory planning improvement, which is aimed at the sustainable development of regions is a challenge for most countries (Giovarelli \& Bledsoe, 2001; Verkhovna Rada of Ukraine, 2003; Malashevskyi \& Bugaienko, 2016a; Vitikainen, 2004; Hartvigsen, 2014, 2015; Food and Agriculture Organization of United Nations [FAO] 2003, 2004). Social, economic and environmental aspects of land use are carefully studied. The improvement of industrial and agricultural manufacturing, employment, infrastructure, environment and housing facilities as the result of the goal-oriented land management are of special interest (Vitikainen, 2004; Hartvigsen, 2015; FAO, 2003, 2004). These issues have been discussed at international conferences, for instance, FAO workshops in the Europe and Central Asia region on Land tenure - since 2002. In order to reach the goal, the measures on consolidation and reallocation of land, including buying and selling,

*Corresponding author. E-mail: palamar1alena@gmail.com 
exchanging and leasing of land, etc. are realized (De Moor, 2015; Thomas, 2006; Demetriou, 2014; Giovarelli \& Bledsoe, 2001; Sulonen \& Kotilainen, 2016). In this regard, it is necessary to further study the mechanisms of land redistribution, among which, the exchange is the basic, taking into account the objective spatial limitation and the crucial role of land in production and placement. Particular attention should be paid to the possibilities and prospects for a land exchange in the light of the main tasks of modern land management.

\section{Materials and methods}

Land exchange is considered as the main method of removing the agricultural land tenure defects in the Soviet (Udachin, 1962; Hendelman, Zapletin, \& Shuleikin, 1986; Hendelman, 1978) and Ukrainian literature sources. In the materials of the international conferences on land consolidation and land banks, the land exchange is considered in the context of land use and land tenure improvement. There is a set of legal researches on land parcel exchange agreements.

The issues related to the land exchange are given a secondary role in existing works, they are considered narrowly and limited by the problems chosen by the authors, a comprehensive analysis is absent. The separate proposals on the land plots evaluation during exchange are made, but the general mechanisms are not formulated. The aim of the research is to define and systematize the preconditions and general possibilities for a land exchange in the modern conditions of Ukraine. Traditionally, inter-farm land management should take into account the need to maintain the size and spatial location of each land use within unchanged limits for a long time (Verkhovna Rada of Ukraine, 2003, 2004). This principle is particularly important in the conditions of land private ownership when changes in the boundaries and dimensions of land use require a comprehensive study and should be carried out with minimal disruption to the landowner. Therefore, it is necessary to consider the possibility and feasibility of land exchange in the context of the objective preconditions of inter-farm land management (Figure 1).

\section{The land use placement lacks and their boundaries}

These lacks include outlands (Figure 2a), cutting-in (Figure $2 b$ ), strip farming (Figure 2c), including topographic (Figure 3a), cutting-in and broken boundaries (Figure

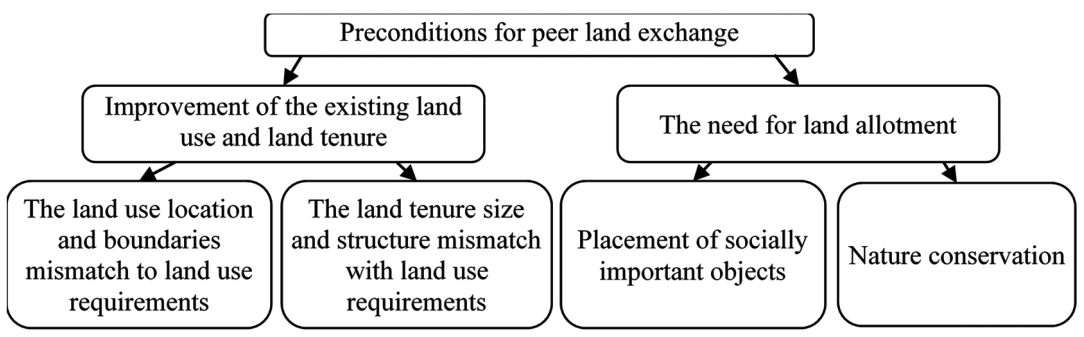

Figure 1. The peer exchange of land as part of inter-economic land management in Ukraine

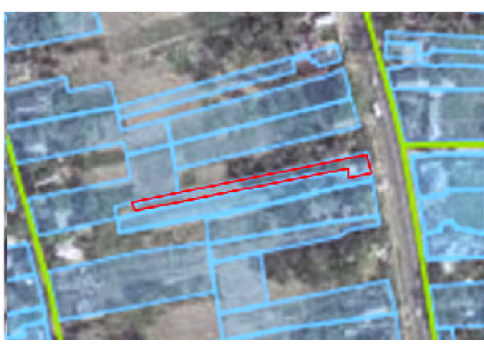

a)

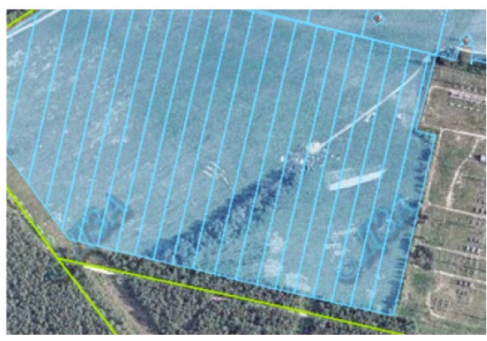

a)

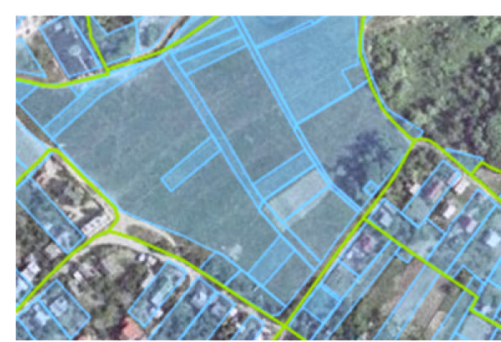

b)

Figure 2. Land massive placement lacks

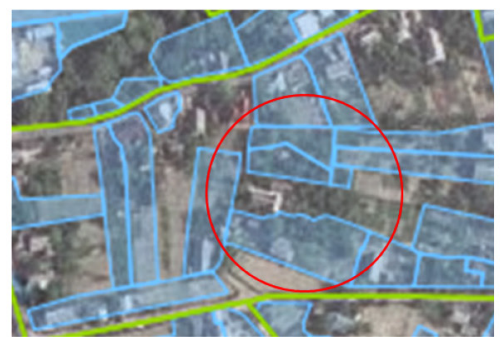

b)

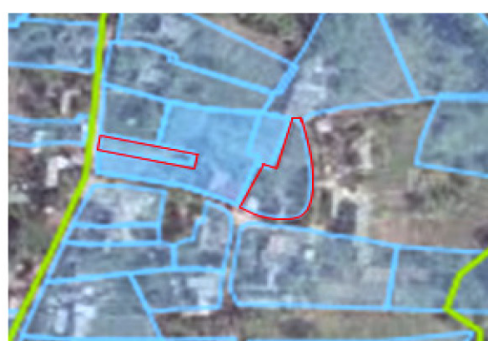

c)

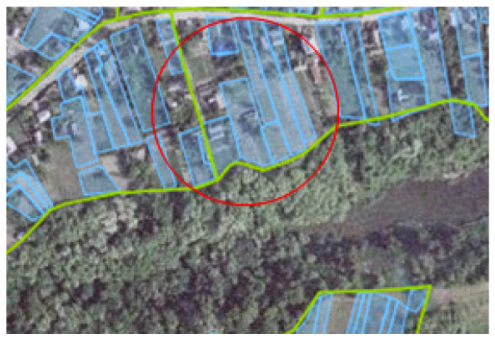

c)

Figure 3. Land massive boundaries 
$3 b$ ), erosionally dangerous location of land use boundaries (Figure 3c) (Public Cadastral Map of Ukraine as of August 2016).

The land use placement lacks and their boundaries is the reason for the decrease in the level of land use, the productivity of machinery and transport units, the increase in costs for idle turns, arrivals and crossings, there are additional costs for creating engineering infrastructure of the territory, etc. (Vitikainen, 2004).

Elimination of these lacks is most effective through the exchange of equivalent land plots, the exchange of unequal land plots with monetary compensation, as well as land reorganization. Equivalent land exchange in the general case is the main measure of eliminating stripes, strip farming, outlands, wedging, broken boundaries. If there are additional local conditions and requirements, complex cases of the topographical intersection, the need to reorganize land use from the procedure of equivalent exchange is the derivative of the organization of an unequal exchange with monetary compensation. The inconsistency between the size and structure of land use to the needs of production and land use needs:

- the existing size and structure of land use;

- as a result of changes in land use conditions.

\section{Results}

As a result of large-scale economic transformations in recent decades, the changes in both the land use structure and the property relations themselves have taken place. The development of various forms of management, as expected, has led to stricter requirements for the intensification of land use and protection of land rights. Accordingly, at present, the issue of consolidation of agricultural plots fragmented as a result of sharing, improvement of urban territories based on rational placement and optimization of land use dimensions of industrial, transport and other non-agricultural facilities has become a matter of concern. In addition to the above tasks of land management, based on the existing structure of land use, the ways of improving the territorial organization in case of changing land use conditions should be determined. For example, as a result of urban development, there is a need to change and establish the boundaries of settlements.

In each case, a redistribution of land is required, which will affect the interests of private owners, territorial communities and the state. At the same time, the exclusive role of lands as a spatial basis and factor of production must be taken into account. That is why an equivalent exchange has the prospect of becoming a basic mechanism for resolving the issues of improving the land use system. To solve the tasks of inter-farm land management, an equivalent exchange can be a component of technical documentation on land management with regard to the consolidation of land plots, land management projects for the improvement of the territory of settlements, land management projects for establishing (changing) the boundaries of administrative-territorial entities, land management projects to streamline the existing land tenure and land use (Table 1) (Rembold, 2002).

One of the urgent tasks for creating natural conditions for life and human development, observance of ecological

Table 1. Peer land exchange at land surveying in Ukraine

\begin{tabular}{|c|c|c|}
\hline $\begin{array}{l}\text { Preconditions for inter } \\
\text { economic land surveying }\end{array}$ & Land surveying documentation type & Activities involving an equivalent land exchange \\
\hline Shortcomings in land use & $\begin{array}{l}\text { Land management projects to streamline } \\
\text { existing land tenure and land use }\end{array}$ & $\begin{array}{l}\text { Elimination of wedging, fracture of boundaries, } \\
\text { strip farming, (including topographic) inclusions, } \\
\text { outland, the erosionally hazardous location of land } \\
\text { use boundaries }\end{array}$ \\
\hline $\begin{array}{l}\text { The inconsistency of land use } \\
\text { parameters with the needs } \\
\text { of production and land use } \\
\text { objectives: } \\
\text { a) the existing size and } \\
\text { structure of land use }\end{array}$ & $\begin{array}{l}\text { Technical documentation on land } \\
\text { management on the division and } \\
\text { consolidation of land plots. Land } \\
\text { management projects for streamlining } \\
\text { settlements }\end{array}$ & $\begin{array}{l}\text { Exchange of land in the process of consolidating } \\
\text { agricultural land or in the process of optimizing } \\
\text { the size of non-agricultural land use }\end{array}$ \\
\hline $\begin{array}{l}\text { Caused by changing land use } \\
\text { conditions }\end{array}$ & $\begin{array}{l}\text { Land management projects for } \\
\text { establishing (changing) the boundaries of } \\
\text { administrative-territorial units }\end{array}$ & $\begin{array}{l}\text { Exchange of land plots under the jurisdiction of } \\
\text { various administrative and territorial units for } \\
\text { the purpose of establishing and changing the } \\
\text { boundaries of administrative-territorial units }\end{array}$ \\
\hline Protection of lands, nature & $\begin{array}{l}\text { Land management projects for the } \\
\text { organization and establishment of the } \\
\text { territories boundaries of the nature reserve } \\
\text { fund and other nature protection purposes, } \\
\text { recreational and historical-cultural } \\
\text { purposes }\end{array}$ & $\begin{array}{l}\text { Reorganization of existing land use in order to } \\
\text { allocate the land for environmental protection } \\
\text { objectives }\end{array}$ \\
\hline $\begin{array}{l}\text { The need for social importance } \\
\text { objects placement }\end{array}$ & $\begin{array}{l}\text { Land management project for the creation } \\
\text { of new land tenure and land use }\end{array}$ & $\begin{array}{l}\text { Reorganization of existing land use for the } \\
\text { purpose of allocating land for the construction } \\
\text { and operation of facilities in national } \\
\text { interests or interests of the territorial community }\end{array}$ \\
\hline
\end{tabular}


balance, conservation of biological diversity is the increase of the areas of the national ecological network by means of assigning a part of the lands of economic use to categories, which are subjected to special protection (Verkhovna Rada of Ukraine, 2000). A change in the land use is possible without prejudice to landowners, in the event of the exchange of land plots, which are provided for environmental purposes by equivalent land plots. With this approach, the effectiveness of the environmental programs is objectively increased.

In this case, it is necessary to consider objects of exceptional importance for the population and the state as a whole, the placement of which is considered in the context of meeting social needs, and as a public necessity.

The methodology of peer exchange (Malashevskyi \& Bugaienko, 2016a; Chibiriakov, Malashevskyi, \& Bugaienko, 2016; Sydorenko, Malashevskyi, \& Lytvynenko, 2016) is implemented in the production process in the procedure of alienation of land plots during the construction of the high ringway around Kyiv within the Krushinsky village council of the Vasylkivsky district of the Kyiv region (Figure 4). According to the adopted scheme of the general direction of the high ringway, 9 areas of designing are defined. The land plot provided for allocation within the Krushinsky village council is included in area No. 5 of the high ringway, which runs along the lands of Markhalivsk, Krushinsk, Ivankovichivsk, Roslavichivsk, Gvozdivsk village councils of Vasylkivskyi district of the Kyiv region and Pidhirtsivsk, Velikodymytrovitsk, Starobesradichevsk village councils and Kozinsky village council of the Obukhiv district of the Kyiv region.

The land plots are allocated for permanent use to the Roads Service in the Kyiv region, the estimated area of which is about 24 hectares, among them: $85 \%$ is subject to alienation from landowners; $15 \%$ are the lands, which not transferred to ownership or use.

The calculation of equivalent land plots is represented by the formula:

$$
S_{2}=\frac{S_{1} \times Q_{1} \times K_{k 1} \times K_{r 1} \times K_{l 1}}{Q_{2} \times K_{k 2} \times K_{r 2} \times K_{l 2}},
$$

where $S$ - is the land plot area; $Q$ - is the soil quality score of land plot (Chibiriakov et al., 2016); $K_{k}-$ is the coefficient characterizing the configuration of the land plot (Malashevskyi \& Bugaienko, 2016b); $K_{r}$ - is the coefficient characterizing relief; $K_{l}$ - is the coefficient characterizing the fracture of boundaries.

At the same time, the land plots offered for exchange will be as follows:

$$
\begin{gathered}
P_{2}(\text { plot. } 17,18)=\frac{5.3460 \times 45 \times 0.63 \times 0.99 \times 0.98}{42 \times 0.71 \times 1.00 \times 0.98}=5.00 \\
\text { hectares; } \\
P_{2}(\text { plot. } 19)=\frac{0.5197 \times 45 \times 0.71 \times 0.99 \times 0.98}{42 \times 0.71 \times 1.00 \times 0.98}=0.54 \\
\text { hectares; }
\end{gathered}
$$

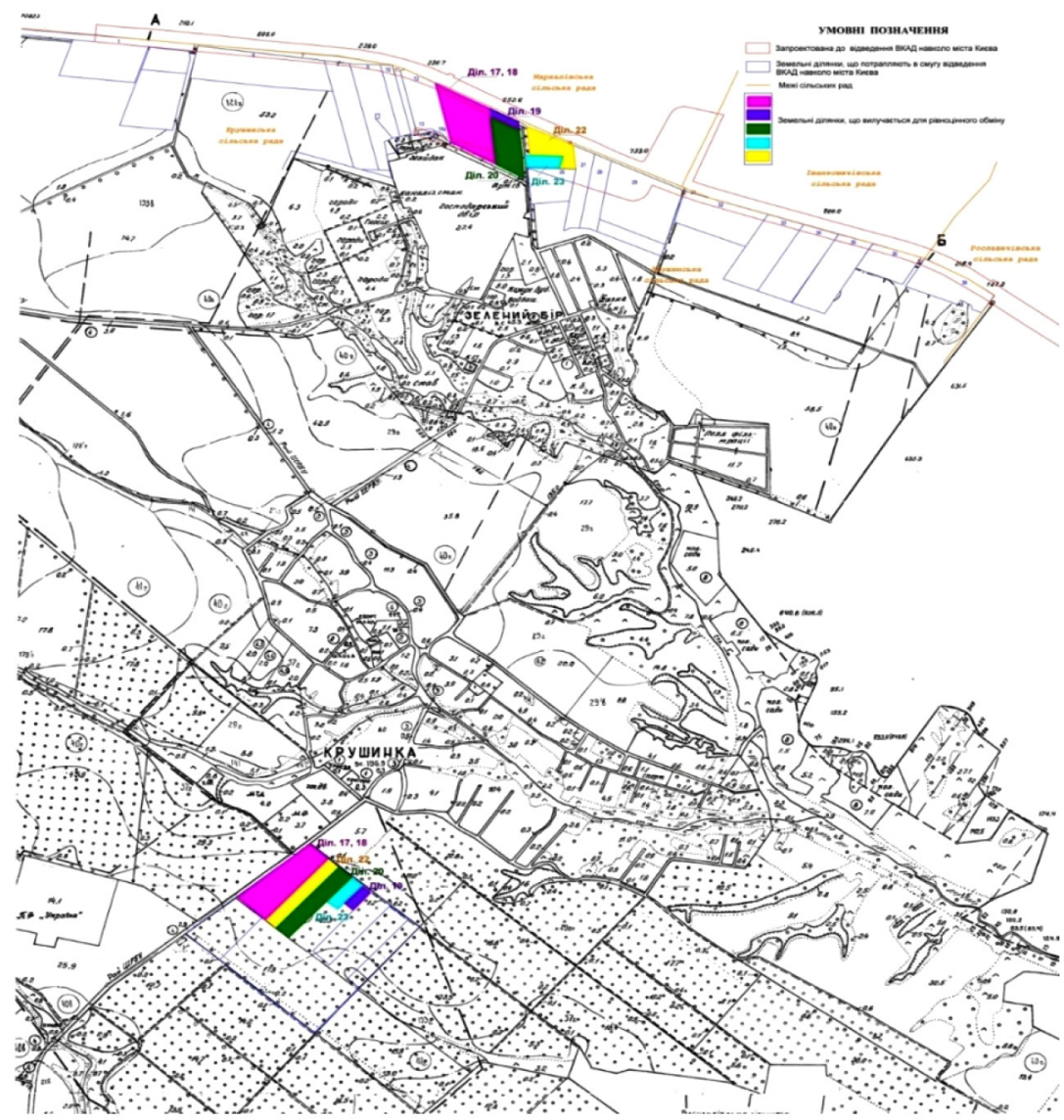

Figure 4. Determination of land plots for peer exchange within Krushinka village of Vasilkovsky district of the Kyiv region 


$$
P_{2}(\text { plot } .20)=\frac{2.6773 \times 45 \times 0.71 \times 0.99 \times 0.98}{42 \times 0.71 \times 1.00 \times 0.98}=2.83 \text { hectares; }
$$

$$
P_{2}(\text { plot } .22)=\frac{2.1569 \times 45 \times 0.63 \times 0.99 \times 0.98}{42 \times 0.71 \times 1.00 \times 0.98 \quad}=2.02
$$

$$
P_{2}(\text { plot. } 23)=\frac{0.8999 \times 45 \times 0.63 \times 0.99 \times 0.98}{42 \times 0.71 \times 1.00 \times 0.98 \quad}=0.84 \text { hectares. }
$$

\section{Conclusions}

The research of inter-farm land management features allows identifying the main preconditions and general possibilities for peer land exchange in the modern conditions of Ukraine. The general characteristic is given and the expediency of realization of actions on the rationalization of land use with the use peer land exchange is proved. The main types of land management documentation, which may include certain procedures are defined.

\section{Funding}

The research has no funding.

\section{Author contributions}

Mykola Malashevskyi conceived the study and were responsible for the design and development of the data analysis. Evgen Tarnopolsky, Mariia Malanchuk were responsible for data collection and analysis. Olena Bugaienko and Alena Palamar were responsible for data interpretation.

\section{Disclosure statement}

Authors have no competing financial, professional, or personal interests from other parties.

\section{References}

Chibiriakov, V., Malashevskyi, M., \& Bugaienko, O. (2016). The development of peer agricultural land plots calculation methodology at the exchange process. Engineering Geodesy, 62, 72-80.

De Moor, A. (2015, January 27-28). Urban land reallotment. Paper presented at the Geodesign. Summit Europe, Salzburg.

Demetriou, D. (2014). The development of an integrated planning and decision support system (IPDSS) for land consolidation. Switzerland: Springer International Publishing. https://doi.org/10.1007/978-3-319-02347-2

Food and Agriculture Organization of United Nations. (2003). The design of land consolidation pilot projects in Central and Eastern Europe (FAO Land Tenure Studies No. 6). Retrieved from http://www.fao.org/docrep/006/Y4954E/y4954e00.htm
Food and Agriculture Organization of United Nations. (2004). Operations manual for land consolidation pilot projects in Central and Eastern Europe. FAO Land Tenure Manuals 1. Retrieved from http://www.fao.org/nr/lten/abst/lten_071001_ en.htm

Giovarelli. R., \& Bledsoe, D. (2001). Land reform in Eastern Europe. Western CIS, Transcaucuses. Balkans and EU Accession Countries. Seattle, Washington: FAO. Retrieved from: http:// www.fao.org/3/a-ad878e.pdf

Hartvigsen, M. (2014). Land reform and land fragmentation in Central and Eastern Europe. Land Use Policy, 36, 330-341. https://doi.org/10.1016/j.landusepol.2013.08.016

Hartvigsen, M. (2015). Experiences with land consolidation and land banking in Central and Eastern Europe after 1989 (FAO Land Tenure Working Paper 24). Retrieved from http://www. fao.org/3/a-i4352e.pdf

Hendelman, M. A., Zapletin, V. Ya., \& Shuleikin, A. D. (Eds.). (1986). Zemleustroitelnoe proektirovanie. Moscow: Agropromizdat (in Russian).

Hendelman, M. A. (Ed.) (1978). Nauchnye I metodicheskie osnovy zemleustroistva. Moscow: Kolos (in Russian).

Malashevskyi, M., \& Bugaienko, O. (2016a). The substantiation of urban habitats peer land exchange in Ukraine. Geodesy and Cartography, 42(2), 53-57. https://doi.org/10.3846/20296991.2016.1198568

Malashevskyi, M. A., \& Bugaienko, O. A. (2016b). The substantiation of land plot configuration data at peer exchange. Geodesy, Cartography and Aerial Photography, 83, 100-111.

Rembold, F. (2002). Land fragmentation in CEEC: An overview. In Documentation of the International Symposium on Land Fragmentation and Land Consolidation in Central and Eastern European Countries (pp. 27-28). Munich: Technical University of Munich.

Sydorenko, V. D., Malashevskyi, M. A., \& Lytvynenko, L. V. (2016). Compensation calculation for alienation of land for public purposes in the case of reconstruction of Kyiv great ring road. Technology Audit and Production Reserves, 6(30), 25-34. https://doi.org/10.15587/2312-8372.2016.74828

Sulonen, K., \& Kotilainen, S. (2016). Lessor's status in land consolidation in Europe - Reports from Cyprus, Finland, France, Germany, the Netherlands, Latvia and Estonia. Baltic Journal of Real Estate Economics and Construction Management, 3(1), 56-71. https://doi.org/10.1515/bjreecm-2015-0007

Thomas, J. (2006). Attempt on systematization of land consolidation approaches in Europe. Zeitschrift für Geodäsie, Geoinformation und Landmanagement, 131(3), 156-161.

Udachin, S. A. (1962). Zemleustroitelnoe proektirovanie (4th ed.). Moscow: Selkhozizdat (in Russian).

Verkhovna Rada of Ukraine. (2000). About the national program of formation of the national ecological network of Ukraine for 2000-2015 years: Law, Program of 09.09.2000 No. 1989-III. Information of the Verkhovna Rada of Ukraine, 47, Art. 405.

Verkhovna Rada of Ukraine. (2003). The law of Ukraine on land management. Retrieved from http://zakon3.rada.gov.ua/laws/ show/en/858-15

Verkhovna Rada of Ukraine. (2004). The law of Ukraine on ecological network of Ukraine. Retrieved from http://zakon3.rada. gov.ua/laws/show/1864-15

Vitikainen, A. (2004). An overview of land consolidation in Europe. Nordic Journal of Surveying and Real Estate Research, 1(1), 25-44. 